\title{
A ROGUE BY ANY OTHER NAME
}

\section{Han, Finn, and the Reluctant Resistance}

\section{John Edward Martin}

Keywords

Myth, Archetype, Rogues

Star Wars is a story about heroes-and not just any heroes: mythic heroes and their journeys. That is, according to both popular wisdom and the creator of the mythos, George Lucas himself, who said in his famous 1999 interview with Bill Moyers that, "When I did Star Wars, I consciously set about to recreate myths, and the classical mythological motifs-and use those motifs to deal with issues that existed today."[Emphasis added] ${ }^{1}$ Though he's vague on the particular issues to which he thought these myths might apply, Lucas is clear on the centrality of the Hero as the figure most in need of revitalization for modern audiences, which he feels have lost sight of the value and purpose of mythic heroes.

Indeed, all of the Star Wars films up to this point focus much of their attention on a variety of traditional cultural heroes: soldiers and generals, knights and adventurers, freedom fighters and rebels, wise men and their acolytes. And, of course, there are the Chosen Ones-those heroes whose journeys drive the narrative through their own moral, spiritual, and psychological aspirations; namely, Anakin, Luke, and most recently, Rey (the "Skywalkers"?). We know they are "chosen" by virtue of their mysterious parentage, their innate affinity for The Force, and by the fact that they all carry the same weapon-the Excalibur, if you will, of the Star Wars universe. Such heroes, while superhuman and exceptional in every way, supposedly represent the deepest truths about our collective humanity: that beneath our common-place origins and human flaws, we have something in us that touches the divine. Following in the philosophical footsteps of his one-time mentor, Joseph Campbell, Lucas adopts the idea that, "myth is the secret opening through which the inexhaustible energies of the cosmos pour into human cultural manifestation." And it is through these heroes and their monomythic journeys of departure, initiation, and return that those cosmic energies are made manifest. 
But I'm not here to talk about heroes-at least not those heroes. I'm here to talk about another class of characters in the Star Wars universe who, if not quite so aspirational or so chosen, clearly represent a much larger demographic, in their world as well as in ours. These are the rogues. Those of you who come from a role-playing fandom already have an idea of what I mean by rogues. These are the characters who operate just outside or on the margins of what we might call the social order, as well as in a tangential role to the central hero's journey. They are neither heroes nor villains, by nature, but often become one or the other by necessity, or by chance. Like heroes, they come in a variety of flavors and archetypes: you have your thieves and outlaws, your conmen and smooth criminals, your mercenaries and militants.

You also have those that I'm calling "the Dispossessed"-the disowned, the disenfranchised, the disposable. These include many of the non-human inhabitants of the Star Wars universe (from Wookies to Ewoks to Porgs), those who have experienced slavery or oppression (including Shmi \& Anakin as well as Chewbacca), and those whose status as sentient beings is often called into question (particularly droids). They represent a different kind of rogue that I'll be discussing more in a moment. Keep in mind, though, that not everyone chooses to be a rogue, just as not everyone chooses to be a hero. We don't all get to channel "the inexhaustible energies of the cosmos," though we all must deal with the consequences of those who do. You'll notice that Anakin appears in both lists, as a hero and a rogue (specifically, one of the Chosen and one of the Dispossessed), and eventually, as a villain or monster-the other archetype that's central to mythic narratives. The fact that Anakin plays all these roles at one time or another reinforces the idea of his centrality to the Star Wars narrative; though one could argue that Luke, too, is dispossessedhe is an orphan, after all-and perhaps monstrous, at least in the eyes of Kylo Ren in the most recent film, The Last Jedi. Of course, it remains to be seen if Rey will follow a similar course, as some fan theories have suggested, but that would be consistent with the cyclical nature of the Hero's Journey and Campbell's monomythic narrative structure.

And then there's Han Solo, the ultimate rogue archetype-a smuggler, a trickster, a cowboy, and a rebel, in more ways than one. He is also a hero, of course, but one who follows a very different path than the one laid out in Campbell's Hero with a Thousand Faces. It's this alternate path that interests me most, because I believe it's one that plays an important, if less heralded, role in the larger mythos than that of the Chosen Ones. It also reveals some important tensions, fissures, and social undercurrents that may be a bit closer to us, in time and in cultural relevance, than those elaborated by Campbell or by Lucas himself, at least in his overt commentaries on the films [Lucas never mentions Han once in the Moyers interview]. In creating Han and Chewbacca, and placing them so firmly at the center of the original story along with Luke, Leia, and Vader, Lucas may have been hinting, consciously or unconsciously, at some of these alternate narratives-the rogue narratives, if you will-that have since become even more important to the social and cultural vision of the Star Wars universe, particularly in the more recent films. But what are these narratives and why are they important, particularly to our understanding of resistance?

Looking back at Andrew Gordon's seminal 1978 essay, "Star Wars: A Myth for Our Time"the same essay that made the connection between Star Wars and Campbell's Hero with a Thousand Faces-I would note that the first half of essay doesn't deal with the heroic monomyth at all, but rather with Lucas's debts to American popular culture, particularly pulp science fiction, Edgar Rice Burroughs novels, comic books, The Wizard of $\mathrm{Oz}$, and American Western films. Gordon writes that, "Lucas has created a myth for our times, fashioned out of bits and pieces of 
twentieth-century American popular mythology...[he] has raided the junkyards of our popular culture and rigged a working myth out of scrap." 3

This image of rigging myths out of junkyard scraps recalls a number of scenes throughout the Star Wars franchise: from the Jawas and their sandcrawlers in Episode IV, to Anakin and Luke's droid-building workshops, to Rey's scavenging for parts in the opening scenes of The Force Awakens. But it particularly resonates (for me) with the multiple scenes of Han and Chewie scrounging amid the clutter and wreckage of the Millenium Falcon, their own flying junkyard, for some last-minute fix to rescue them from impending disaster-an effort that fails nearly as often as it succeeds [“It's not my fault!"].

In fact, it is just this element of haphazardness, of uncertainty, and of frequent failure that tends to distinguish what we might call the "Rogue's Journey" from that of the Hero. Because rogues don't have the benefit of a special bloodline, a mystical energy, or some elite training to help them along, they must rely on something more mundane and perhaps unreliable: a survival instinct, a resourcefulness born of necessity, a good blaster. As a result, their motivations tend to focus less on fulfilling a prophetic destiny or supporting a noble cause than on the more immediate and material needs of the moment. This is more than just a difference of character-it is a difference of class (and I don't mean "character class" but social class).

In a 2006 essay, "Eugenics, Racism, and the Jedi Gene Pool," Matthew Wilhelm Kapell, argues that the themes of resistance, rebellion, and even individuation in the first two Star Wars trilogies are often undermined by their reliance on tropes of biological elitism and hereditary power-both characteristics of the classic mythic Hero (though he may have "humble origins"). By focusing so much of the story around these heroes and their special destinies, the liberating nature of their rebellion against the Evil Empire is called into question. He writes that, "the heroes and villains of the series manage to overthrow one elitist system in favor of another. Their powers to dominate as oppressors or liberators are rooted in their own elite biology. This thorough re-importation of aristocratic and biological justifications of individual worth confounds the often-ascribed message of rebellion against tyranny". 4

That is to say, a story about the struggles and destinies of special people with special powers, light or dark, hardly speaks to the plight of the masses of average people, not to mention marginalized peoples, who are supposed to be the beneficiaries of all these cosmic conflicts. While the Force may bind us all together in mystic unity, only those with specific bloodlines, biological traits (midichlorian count?), or elite educations can directly access and manipulate this Forcehardly a foundation for a more equitable society. While readers like Campbell and Lucas may argue that we can all identify with the journey of the hero because it is an archetype of all human journeys towards individuation, I think we must recognize that the representation of these characters, especially in a visual medium, is NOT universal or inclusive, especially when combined with an implicit theology that values exceptionalism and elitism over commonality or equitability.

Interestingly, this paradigm of exceptionalism, especially in regard to the Force, has already been subverted in some of the more recent films, where we see a number of characters who display some skill, or at least sensitivity, with the Force, even if they lack the traditional Jedi or Sith bloodlines: Chirrut Îmwe in Rogue One, Maz Kanata in The Force Awakens, the young "broom boy" in The Last Jedi, and possibly in Rey herself (thus, the question of her parentage becomes even more significant). Notably, all of these characters might be classified as rogues or "dispossessed" people who represent marginalized classes within this social world, and each 
resists that imbalance of power in their own subversive or rebellious way. Their sensitivity to and use of the Force is, perhaps, one such act of resistance.

But I want to suggest that a counter-narrative of class and power, resistance and rebellion, has been a part of Star Wars from the beginning, and that it has shaped the more recent vision of the mythos perhaps more profoundly than the narrative of the Hero's Journey. Of course, that counter-narrative arguably begins with Han Solo and Chewbacca. In keeping with Gordon's "scrap-yard mythology", it's clear that Han is an amalgamation of figures from the popular fiction of George Lucas's childhood: a cowboy, a pirate, an ace pilot-part Errol Flynn, part Lone Ranger. But, like the Lone Ranger, and despite his name-a name we now know is given to him by an Imperial bureaucrat-Han has never been a solo character. He has, from the very beginning, been part of a team-a team that includes another rogue, and a one of that special class of dispossessed characters whose rogue identity is as much a product of his race, class, and legal status as it is a product of his choices. Chewbacca is a member of a people who have been persecuted, enslaved, and exiled as a part of the Galactic Empire's expansionist agenda and intolerance of dissent. That is to say, they are a colonized people, a cultural Other. Chewie's loyalty to Han, beyond mere friendship, is a result of a moral and social code that includes "life debts" and "honor families"it is part of a belief system that has nothing to do with Jedi prophecies or Sith ambitions or the balancing of cosmic forces. It is an alternate cultural system that operates seemingly in the margins of the larger mythos that defines the Star Wars universe.

Both Han and Chewie enter the story, not like the Lone Ranger and Tonto, fighting outlaws or righting wrongs in the Old West, but rather, as outlaws themselves-mercenary smugglers looking for their next job while evading various authorities, both legal and criminal. Their eventual conscription into the Rebellion and the struggle against the Empire is less a matter of adopting a noble cause than it is a matter of personal survival, later friendship, and eventually, love (of both the romantic and the philial kind). Their rebellion isn't a mythic journey of individuation so much as it is a flight, so to speak, towards liberation-in a social, political, and economic sense. What they want, more than a great destiny, is simply to be free and easy.

Those of you who study American literature may recognize the reference to another piece of classic American literature and popular culture, and to two other friends, also of different ages, races, and social classes, who come together to seek their freedom. I'm referring, of course, to Huck and Jim fleeing down the Mississippi River on their ramshackle raft [their Millenium Falcon?] in search of some vague promise of liberation from those social systems and political institutions that have oppressed them both in different, but similarly brutal ways. Huck, an abused child, and Jim, a chattel slave, have little in common other than their need to escape-yet their experiences aboard the raft reveal some deeper connections and aspirations that are obscured by their social differences: Jim's longing for his own children and family echoed in his growing affection for Huck; Huck's fear of abandonment and damnation, even by those who have abused him in the past; their mutual desire to attain some sense of self-determination and autonomy, even if it comes through exile.

The parallels with Han and Chewie may not necessarily be apparent in the original Star Wars trilogy, but the recent release of Solo: A Star Wars Story (2018) brings some of these themes more clearly into focus. ${ }^{5}$ In that film, we see that Han isn't the free-wheeling cowboy or wandering outlaw of the earlier films, but rather, an orphaned street-urchin, surviving by his wits and daring in an urban environment--perhaps a little more Tom Sawyer meets Artful Dodger than Huck Finn, but still enthralled to an abusive "parent"-figure, the Lady Proxima, and dreaming of some 
romantic notion of freedom that likely doesn't exist in his already Imperialized galaxy. Chewbacca, similarly, begins in a situation not substantially different from that of Jim-chained, enslaved, separated from his clan, and treated like an animal. Their initial alliance is, like Huck and Jim's, driven by self-preservation, mutual interest, and, perhaps, a recognition of their shared longings: for freedom, for friendship, and for autonomy. Theirs is an act of resistance against and unjust and oppressive situation. Only later does it become an overt act of rebellion against a system-first, when Han makes the fateful choice to help Enfys Nest and her Cloud-riders against the Crimson Dawn syndicate, and much later, when he chooses to help Luke destroy the Death Star, thus becoming for the first time, a Rebel and a leader.

I don't want to make too much of the Huck \& Jim comparison, except to say that Lucas's borrowings from American cultural history may go deeper than the popular pulp fiction and cinema of his youth (although Huckleberry Finn may have been among these early influences), and that they resonate with social and cultural issues that are not necessarily reflected in the classical mythologies that he overtly adopts as the narrative structure of his epic story. In drawing on these more recent and culturally specific influences, Lucas may have imported some of their political valences, including questions about class, race, and forms of resistance that operate on the social and personal, rather than the cosmic level.

John Shelton Lawrence, in "Joseph Campbell, George Lucas, and the Monomyth," suggests that while the first Star Wars trilogy is heavily influenced by Campbell's Hero's Journey, Lucas's disappointment with Campbell's snobbery towards popular culture led him to move away from the monomyth in his second "prequel" trilogy, which is notably more political and contemporary in its social concerns. ${ }^{6}$ But I am suggesting that Lucas's interest in such topics is already present in the first trilogy, and perhaps indicates his own need to subvert the dominant narrative of heroes and elite bloodlines, even as he recites those myths on the surface.

Which brings us to another Finn-not Huckleberry, but rather, "just Finn." The choice of a name here is interesting, and I am not arguing that it's another reference to the Twain text, though I do find some other important resonances with that story, particularly in the runaway slave motif. I don't think it's an accident that Abrams made the controversial decision to cast a black actor in defiance of some fans' insistence on the canonical "clone" origin of the stormtroopers. Like Han Solo, Finn receives his name, or rather names, from other people: his initial designation, FN2187, is imposed by his First Order masters, those who have raised and conditioned him to serve a particular mechanical and disposable function. His later name, "Finn", is given by Poe Dameron, a new ally and friend, who also offers him a new purpose-one that he is initially hesitant to accept. Their escape from an Imperial Cruiser echoes the escape of Han and Chewie from their own prisons and serves a similar purpose: to forge a friendship out of mutual need and resistance to an oppressive authority. There are other notable parallels between Finn and Han: they are both orphans, both soldiers, both deserters who have rejected the military ethos of discipline and loyalty to the state, and both men are uncertain of who or what they want to be, other than free from their oppressive circumstances.

This uncertainty of identity suggests two things to me: First, a lack of family or bloodline which, unlike the mysterious parentage of the Chosen Ones, is unknown for the opposite reasonbecause it doesn't matter, it's not significant, either in their own lives or in the cosmic scheme of things; they are, quite literally, nobody in this universe (and note, we're still waiting to see if this is true of Rey as well, as was suggested by, of all people, Kylo Ren, the epitome of "noble" bloodlines in this universe). Second, it's because they are both in the process of becoming who 
they are, not through some prophesized destiny or mythic journey, but through something more personal and valuable in their own lives: their choices, and ultimately, their relationships. While both men accept names that are given to them by others, neither easily accepts the identities imposed on them, either as outlaws or heroes.

Finn, we recall, is willing to adopt whatever identity (or uniform) he needs to in order to survive and, eventually, escape. First, he's forced to wear the armor, the white armor, of his First Order masters. And note, he isn't the first rogue to do so-there is a famous image of Han wearing the stormtrooper armor in Star Wars: Episode IV. Later, he adopts the guise of a Resistance fighter, telling Rey on their first meeting, "Yes I am. I'm with the resistance, yeah. I'm with the Resistance! ...Well, this is what we look like. Some of us. Others look different."7 It is, at best, a tentative and opportunistic identification, but one that tells us something about his capacity to work against stereotype or expectation, as well as his willingness to adapt to circumstances; though it may also point to his own uncertainty, having been raised largely without an identity of his own. Only later does he admit, "I'm not who you think I am. I'm not Resistance. I'm not a hero."

This same sentiment is echoed by Han when he first meets Finn and Rey: "You're Han Solo?"...”I used to be." 8 Even now, years after accepting his role as a rebel, a leader, even a general (a military deserter!), Han has trouble embracing those identities as a part of who he really is, just as Finn has trouble seeing himself as anything permanent, especially a hero. In The Last Jedi, he has returned to the only identity he ever felt truly comfortable inhabiting, that of a smuggler and rogue, living on the margins of society with the only companion that shares his sense of displacement and impermanence.

Interestingly, it is Maz Kanata, another rogue with a long history of playing both sides, who points out the crucial similarity between Han and Finn. She first says to Finn, "If you live long enough, you see the same eyes in different people. I'm looking at the eyes of a man who wants to run."9 Moments later, she says something similar to Han, "You've been running away from this fight for too long." ${ }^{10}$ The impulse to run, to escape, to be free of the burden of both oppression and the responsibilities of active rebellion, runs deep in both men, and for similar reasonsbecause neither promises to improve their lot in any significant way, and because neither can embrace the notion of "destiny" or heroic identity. But, while Finn defiantly counters that, "You don't know a thing about me," there is one thing that Maz does know: that it's not the literal, external fight that both men are fleeing, but an internal one-a battle with their feelings of connection to others, their sense of self (or lack thereof), and with the impossible burden of heroism for those who lack all the mythic qualities of "the Hero".

What ultimately brings them back to the fight, though, is precisely these things: loyalty to their friends and loved ones, an emerging or, in Han's case, rediscovered sense of connection, and an acceptance of a role that once seemed too far beyond their limited powers and social position. For Huckleberry Finn, that moment comes when he resolves to rescue Jim, despite his own fears of damnation, proclaiming, "All right, then, I'll go to hell!". For Han, in The Force Awakens, it's when he chooses to confront the one connection and identity that he can't deny: that of "father." And for Finn, it comes in his climactic battle with Captain Phasma in The Last Jedi: "You were always scum," Phasma tells him. "Rebel scum," Finn replies." For Finn, the acceptance of his role as "rebel" is driven, in part, by the defiance of Phasma's, and by extension, the First Order's, authority over him-but also by his now conscious embrace of a communal identity that is shared 
by his only real human connections, Poe, Rey, and Rose Tico. Having risked his life to save each of them, he now finds solidarity in their cause and in its shared purpose: resistance.

Despite their reluctance, Han and Finn discover their sense of purpose and identity in the Resistance, not because of destiny or a heroic journey towards individuation, but through relationships, human connection, and a sense of belonging. Interestingly, if we return to George Lucas's interview with Bill Moyers, he makes clear that, in his mind, the Hero's Journey isn't just about individuation, but about finding one's place in a community and putting that community's needs ahead of your own. ${ }^{12}$ Perhaps the Rogue's Journey (or, in this case, the Rebel's Journey) is ultimately consistent with that of the Hero, though its origins, motives, and mechanisms may differ. The most significant difference seems to be $w$ ho is allowed to take each of these journeys, and why their paths must differ. Since Lucas's original Star Wars trilogy, the centrality of the Skywalker line-with its whiteness, its maleness, its elitism-and of the Hero's Journey, has begun to erode in the face of resistance from both within and beyond the mythos itself. But I've suggested here that the seed of that resistance was there from the beginning, smuggled, as it were, into the margins of the monomythic narrative by two scoundrels in a flying junkyard.

\section{Notes}

${ }^{1}$ The Mythology of Star Wars (with George Lucas and Bill Moyers), directed by Pamela Mason Wagner (2004; Princeton, NJ: Films for the Humanities \& Sciences), DVD. 57 minutes.

${ }^{2}$ Joseph Campbell, The Hero with a Thousand Faces, ${ }^{\text {nd }}$ Edition (Princeton, NJ: Princeton UP, 1972), p. 3 .

3 Andrew Gordon, "'Star Wars": A Myth for Our Time." Literature/Film Quarterly 6, no. 4 (1978): 315. http://www.jstor.org/stable/43795691.

${ }^{4}$ Matthew Wilhelm Kapell, "Eugenics, Racism, and the Jedi Gene Pool”, in Finding the Force of the Star Wars Franchise: Fans, Merchandise, \& Critics, ed. Matthew Wilhelm Kapell and John Shelton Lawrence (New York: Peter Lang, 2006), p. 160.

${ }^{5}$ Solo: A Star Wars Story, directed by Ron Howard (2018; Walt Disney Pictures/Lucasfilm), Film.

${ }^{6}$ John Shelton Lawrence, "Joseph Campbell, George Lucas, and the Monomyth" in Finding the Force of the Star Wars Franchise: Fans, Merchandise, \& Critics, ed. by Matthew Wilhelm Kapell and John Shelton Lawrence (New York: Peter Lang, 2006), p. 21-33.

${ }^{7}$ Star Wars: Episode VII-The Force Awakens, directed by J.J. Abrams (2015; Walt Disney Pictures/Lucasfilm), Film.

8 Ibid.

9 Ibid.

${ }^{10}$ Ibid. 
11 Star Wars: Episode VIII-The Last Jedi, directed by Rian Johnson (2017; Walt Disney Pictures/Lucasfilm), Film.

${ }^{12}$ Wagner, The Mythology of Star Wars. 